\title{
Comparison of Cyanide Levels in Selected Cassava Varieties Cultivated in Lurambi Constituency, Kakamega County Using the Picric Acid Method
}

\author{
Menge Dominic ${ }^{1}$, James Nampushi ${ }^{2}$, Wesley Omwoyo ${ }^{3 *}$, Imali Linda ${ }^{1}$
}

${ }^{1}$ Department of Biological Science, Maasai Mara University, Narok, Kenya

${ }^{2}$ Department of Tourism and Hospitality Management, Maasai Mara University, Narok, Kenya

${ }^{3}$ Department of Chemistry, Maasai Mara University, Narok, Kenya

DOI: $10.36347 /$ simcr.2020.v08i07.025

| Received: 14.07.2020 | Accepted: 22.07.2020 | Published: 30.07.2020

*Corresponding author: Dr. Wesley Omwoyo

Abstract

Original Research Article

Manihot esculenta Crantz (cassava) is a perennial, woody shrub that has an edible root and is grown in the tropics. Cassava is an important source of calories for millions of people in the tropics. However, all cassava varieties contain cyanide which is among the topmost swiftly working poison. This study was aimed at comparing cyanide levels in three cassava varieties grown by residents of Lurambi constituency, Kakamega County for food. These varieties included Migyera, Serere and MH95/0183. Picric acid method was used in this study to assess the cyanide levels in the cassava tubers. A total of twenty-seven cassava tubers of different ages from three farms were used in this study. The average concentration of cyanide in Migyera was the highest $(45 \mathrm{HCN} \mathrm{mg} / \mathrm{kg}$ ) while Serere had the lowest average cyanide concentration (15 HCN mg/kg). Migyera, Serere and MH95/0183 had the highest cyanide level at six months and this cyanide content reduces with increase in age of the tuber, the content of cyanide in Migyera, Serere and MH95/0183 ranged from $15 \mathrm{HCN} \mathrm{mg/kg} \mathrm{to} 30 \mathrm{HCN} \mathrm{mg/kg}$ at twelve months, the cyanide levels in Migyera, Serere and MH95/0183 at twelve months were above the limits of cyanide fit for human consumption by WHO (10 HCN $\mathrm{mg} / \mathrm{kg}$ ), cyanide content for Migyera, Serere and MH95/0183 ranged between $10 \mathrm{HCN} \mathrm{mg/kg} \mathrm{to} 30 \mathrm{HCN} \mathrm{mg} / \mathrm{kg}$ at twelve months forty eight hours after uprooting. Serere had the lowest amount of cyanide post-harvest, $10 \mathrm{HCN}$ $\mathrm{mg} / \mathrm{kg}$. It was concluded that Serere was the only variety that contains cyanide content after post-harvest storage that falls within the WHO accepted limit $(10 \mathrm{HCN} \mathrm{mg/kg})$. It is recommended that Migyera, Serere and MH95/0183 tubers be harvested after twelve months and stored for at least forty eight hours before consumption.

Keywords: Cassava, varieties, Cyanide levels, tubers.

Copyright @ 2020: This is an open-access article distributed under the terms of the Creative Commons Attribution license which permits unrestricted use, distribution, and reproduction in any medium for non-commercial use (NonCommercial, or CC-BY-NC) provided the original author and source are credited.

\section{INTRODUCTION}

Cassava is a shrub characterized by an edible tuber which is cultivated in humid, the tropics and subtropical regions of the biosphere. It is a perennial plant and has its origin in humid regions of America. It was first introduced in Africa in the Democratic Republic of Congo by Portuguese [1]. This tuberous root is one of important starchy staple food for Kakamega residents and Kenya at large. This member of the spurge family Euphobiaceae is an essential food to millions of households living in the tropics. Cassava grades fourth after rice, sugar and corn as a major source of calories for the human diet in the tropical countries [2, 3]. Besides being used as a subsistence crop it is also a source of income for many households in the tropics.
The plant itself has a large number of varieties some of which are classified either bitter or sweet basing on parenchyma root taste. This is linked to the presence of cyanide [4]. A cyanogenic compound is an inorganic or organic element that comprises the cyano group $\mathrm{C}=\mathrm{N}$. This compound must be capable of releasing cyanide. Free cyanide available is the summation of cyanide present either as hydrogen cyanide or cyanide [9]. The cyanide ion is among the most swiftly working poisons. Fatal doses ingested orally usually act in the shortest time probably a few minutes, cyanide poisons by suffocation just as carbon monoxide however; the mechanism is not the same. Instead of inhibiting the human body cells from receiving oxygen, the cyanide compound obstructs oxidative enzymes like cytochrome $\mathrm{C}$ oxidase which is important to each cell in use of oxygen. Oxidases are enzymes containing metal usually iron or copper. 
Cyanide binds tightly to the enzyme cytochrome $\mathrm{C}$ and forms stable cyanide complexes with $\mathrm{Fe} 3+$ ion and inactivates the enzyme system. This study is aimed at comparing cyanide levels in three cassava varieties grown by residents of Lurambi constituency for food. These varieties include Migyera, Serere and MH95/0183.

\section{Methodology}

\section{Study area}

The research was carried out in Lurambi constituency, Kakamega County on cassava varieties already planted by farmers considering the fact that it is a major source of calories for the residents second after maize. Kakamega is in Western Kenya. It lies about $30 \mathrm{~km}$ north of the equator. It lies on latitude 0.282731 $\mathrm{N}$ and latitude 34.751863 E and an elevation 1240-2000 meters above sea level. It has a population of 1,660651 (2009 census) and an area of $3033.8 \mathrm{~km} 2$. Weather is 30 degree Celsius .Humidity is $24 \%$ and wind $\mathrm{NE}$ at $6 \mathrm{mph}$ (ASDSP).

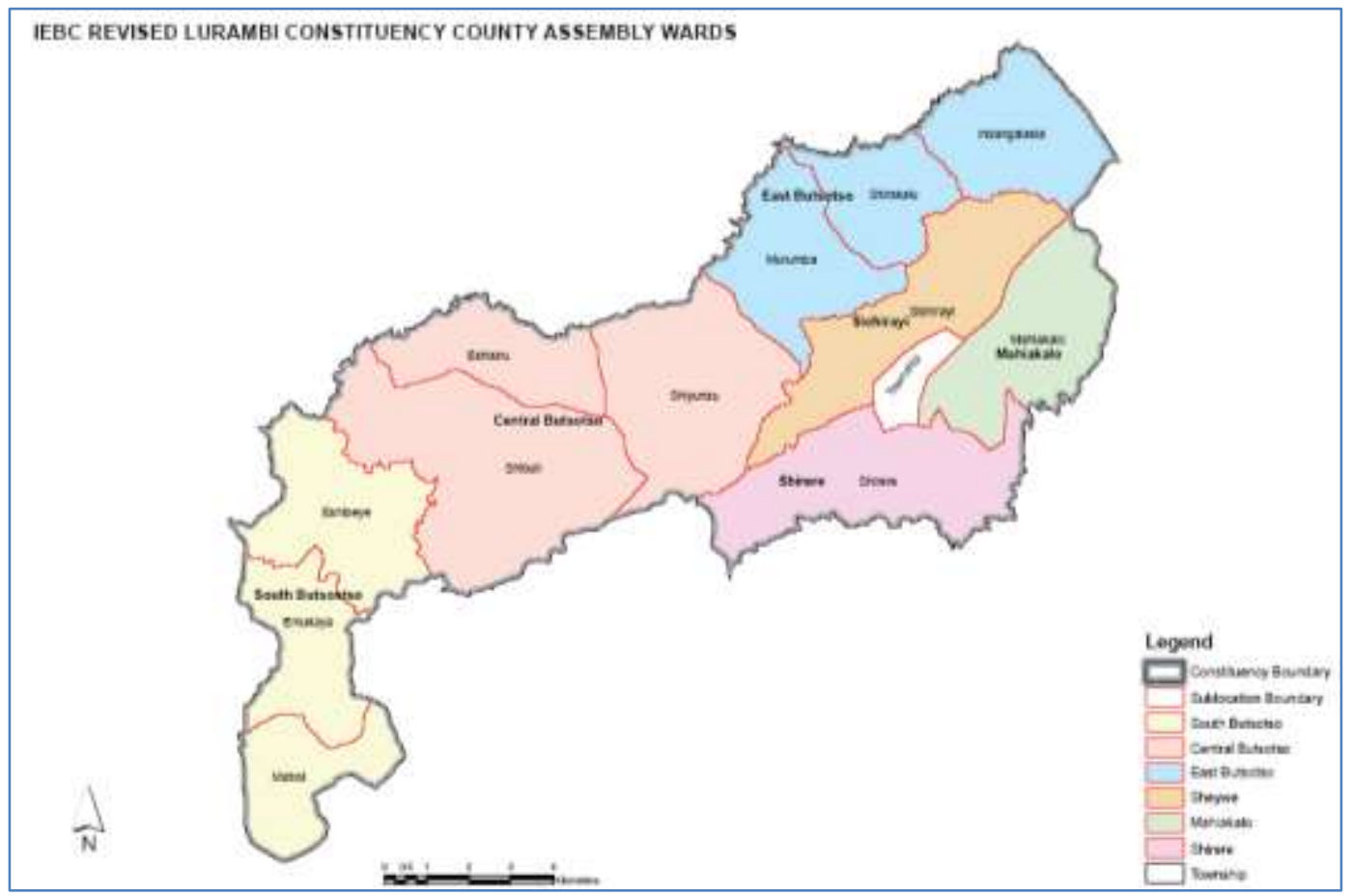

Fig-2: Lurambi map constituency, courtesy of IEBC

\section{Varieties studied}

The varieties used for the research were: $\mathrm{MH}$ 95/0183, Migyera and Serere. Random sampling was used to collect tubers used in the research. Stratified sampling was used to select the tubers from each variety. A total of twenty seven samples were used in this study.

\section{Extraction}

The simplest method easily adaptable by the famers was used to assess the cyanide level so that farmers can even use it locally to test for cyanide before ingesting their cultivars. This is the picric acid method which is a semi quantitative test used to analyze the level of cyanide in food [5]. The tubers of the three varieties at six, eight and twelve months of age were uprooted using a fork jembe and peeled. Using a scalpel the tubers were chopped into small pieces of about $0.5 \mathrm{~cm}^{3}$ and weighed on an electric balance so as to obtain 100grams of Migyera, Serere and MH95/0183 and placed in separate test tubes.
Extraction was done using $20 \mathrm{ml}$ of Toluene Methyl benzene which was added to each of the test tubes containing the chopped cubes.

Picric acid helps to change color of the filter paper of the tubers. This helps to liberate linamarin to release cyanide from the tubers. A filter paper was dipped into $5 \mathrm{ml}$ of picric acid and put on the mouth of the test tubes hence giving the basic color of cyanide. Samples of each variety at six ,eight and twelve months were transported to the Maasai Mara University lab to determine if there is a change in the cyanide levels when the test is carried out 48 hours after uprooting.

\section{Analysis of Cyanide Content}

The color change of the filter paper was recorded based on a cassava cyanogen kit color chart $[6$, 7]. This was done for each variety so as to determine amount of cyanide in Migyera, Serere and MH95/0183 at six, eight and twelve months of age. 


\section{Data Analysis}

Cyanogenic potential of the roots was subjected to analysis of variance (ANOVA) procedure [8].Comparison was then made to determine the age when each variety used that is Migyera, Serere and MH95/0183 has the lowest cyanide levels.

\section{RESULTS}

\section{Cyanide content}

Cyanide was extracted from all the tubers (27/27) used in this study from three farms A, B and C. All three varieties of cassava in this study (Serere, Migyera and MH95/0183) were found to contain cyanide in all the ages $(6,8$ and 12 months).

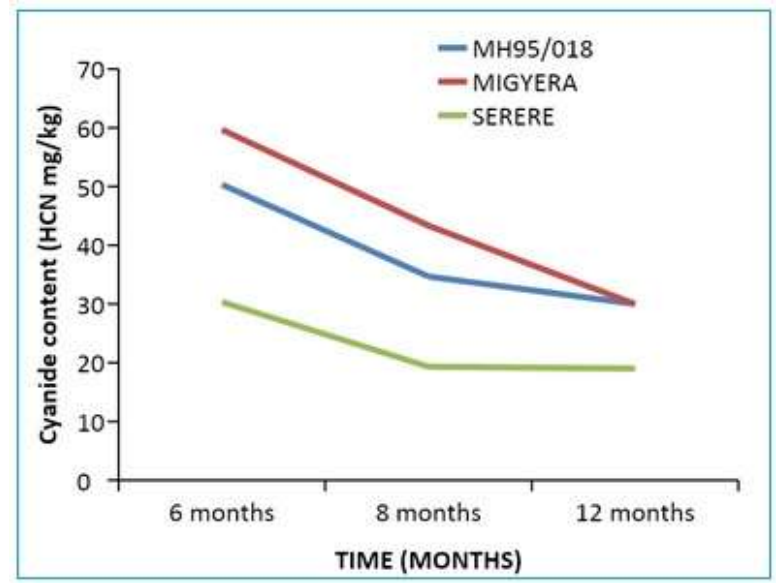

Fig-1: showing average cyanide content in three cassava varieties at different ages post-harvest from farm $A$

The concentration of cyanide generally reduced in with increase in age of the tube varieties. The cyanide levels ranged between $10 \mathrm{HCN} \mathrm{mg/kg}$ to $60 \mathrm{HCN} \mathrm{mg/kg}$ in the twenty seven samples. A decrease in cyanide level was observed after forty eight hours of storage in $100 \%(27 / 27)$ the tubers. The average cyanide content $(\mathrm{HCN} \mathrm{mg} / \mathrm{kg}$ ) of Migyera, Serere and MH95/0183 at 6, 8 and 12 months has been shown in the table below.

Table-1: Table showing average cyanide content (HCN mg/kg) of Migyera, Serere and MH95/0183 at 6, 8 and 12 months

\begin{tabular}{|c|c|c|c|c|c|c|c|c|c|c|c|c|}
\hline \multirow[t]{2}{*}{ VARIETY/FARM } & \multicolumn{3}{|c|}{ FARM A } & \multicolumn{3}{|c|}{ FARM B } & \multicolumn{3}{|c|}{ FARM C } & \multicolumn{3}{|c|}{ AVERAGE } \\
\hline & 6 & 8 & 12 & 6 & 8 & 12 & 6 & 8 & 12 & 6 & 8 & 12 \\
\hline $\mathrm{M}$ & 60 & 45 & 30 & 55 & 40 & 25 & 55 & 45 & 30 & 56.67 & 43.33 & 28.33 \\
\hline $\mathrm{SE}$ & 30 & 20 & 20 & 35 & 25 & 15 & 30 & 25 & 15 & 31.67 & 23.33 & 6.67 \\
\hline ИН95/0183 & 50 & 35 & 30 & 50 & 30 & 30 & 45 & 20 & & 1027 & 7 & 020 \\
\hline
\end{tabular}

Migyera had the highest average cyanide content $56.67 \mathrm{HCN} \mathrm{mg} / \mathrm{kg}$, while Serere had the least, $31.67 \mathrm{HCN} \mathrm{mg} / \mathrm{kg}$ at six months. Migyera had the highest $(60 \mathrm{HCN} \mathrm{mg} / \mathrm{kg})$ cyanide content in the 6 month tuber while Serere had the least $(30 \mathrm{HCN}$ $\mathrm{mg} / \mathrm{kg})$.

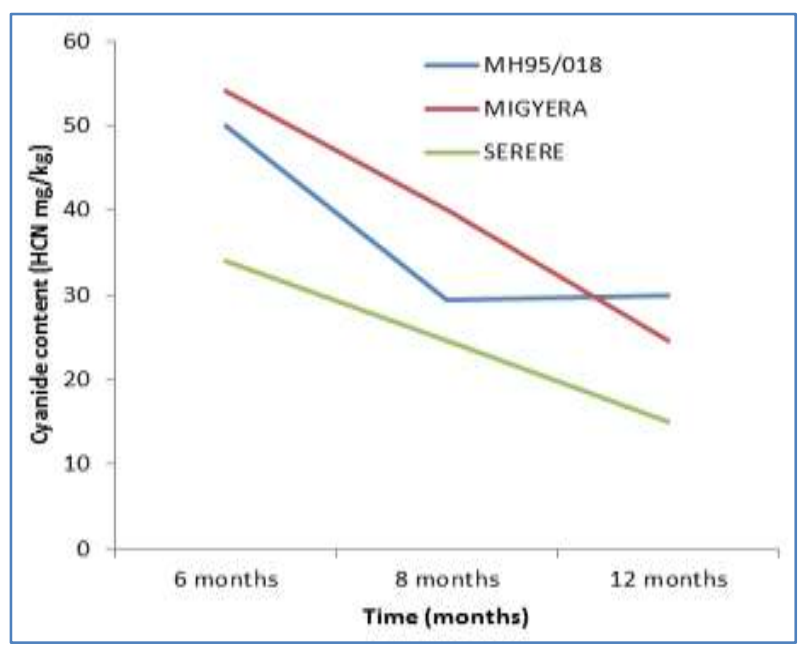

Fig-2: Showing average cyanide content in three cassava varieties at different ages post-harvest from farm $B$ 
Migyera had the highest average cyanide content $40 \mathrm{HCN} \mathrm{mg/kg}$ while Serere had the least 25 $\mathrm{HCN} \mathrm{mg} / \mathrm{kg}$ in Farm B. Migyera had the highest 6 month tuber $(55 \mathrm{HCN} \mathrm{mg} / \mathrm{kg})$ while Serere had the least in the 12 month tuber $(15 \mathrm{HCN} \mathrm{mg} / \mathrm{kg})$.Migyera 6 month tuber and MH95/0183 8 month tuber had the same cyanide content $(31.67 \mathrm{HCN} \mathrm{mg/kg})$. Migyera had the highest deviation between the 6 month tuber and the 12 month tuber $(28.34 \mathrm{HCN} \mathrm{mg} / \mathrm{kg})$ while Serere had the least deviation $(8.34 \mathrm{HCN} \mathrm{mg/kg})$.

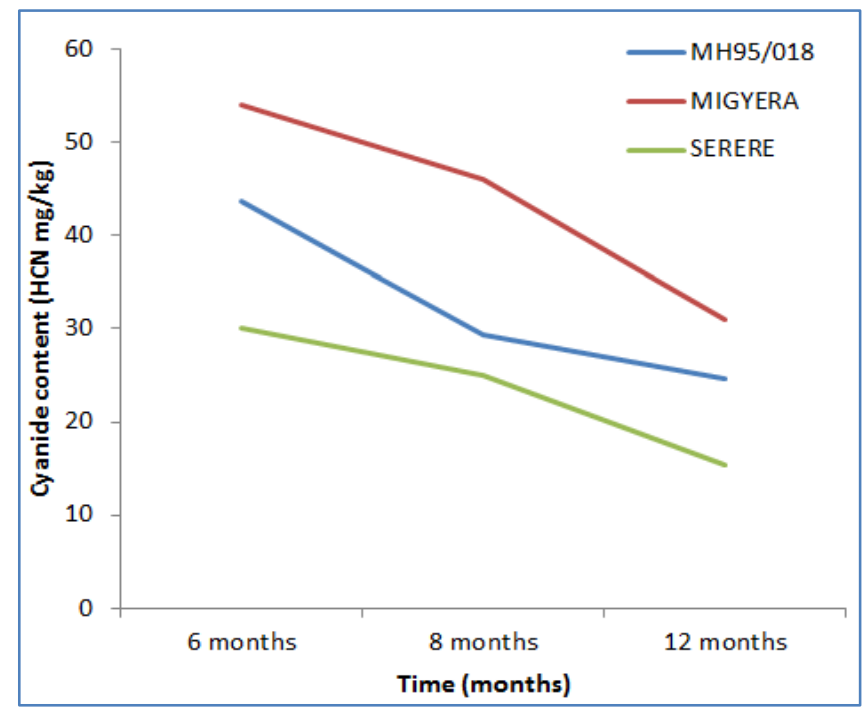

Fig-3: Showing average cyanide content in three cassava varieties at different ages post-harvest from farm C

Cyanide content in Serere and Migyera reduced steadily from 6 to 12 months. Migyera and MH95/0183 had the same amount of cyanide in the 12 month tuber. The table below shows average amount of cyanide post-harvest in Migyera, Serere and MH95/0183.

Table-2: Table showing average cyanide content (HCN mg/kg) in the field and post-harvest

\begin{tabular}{|l|l|l|l|l|l|l|l|l|l|}
\hline \multirow{2}{*}{ VARIETY } & \multicolumn{3}{|l|}{ IN THE FIELD } & \multicolumn{4}{|c|}{ AFTER 48 HOURS } & \multicolumn{3}{|l|}{ DEVIATION } \\
\cline { 2 - 11 } & 6 & 8 & 12 & 6 & 8 & 12 & 6 & 8 & 12 \\
\hline MIGYERA & 56.67 & 43.33 & 28.33 & 50 & 33.33 & 20 & 6.67 & 10 & 8.33 \\
\hline SERERE & 31.67 & 23.33 & 16.67 & 30 & 20 & 10 & 1.67 & 6.67 & 6.67 \\
\hline MH95/0183 & 48.33 & 31.67 & 28.33 & 40 & 20 & 10 & 8.33 & 11.67 & 20 \\
\hline
\end{tabular}

Migyera had the highest 6 month tuber (50 $\mathrm{HCN} \mathrm{mg} / \mathrm{kg}$ ) while Serere had the least cyanide content (20 HCN $\mathrm{mg} / \mathrm{kg}$ ) post-harvest. MH95/0183 and Serere tubers had the same cyanide content $(20 \mathrm{HCN} \mathrm{mg/kg})$ at eight and $(10 \mathrm{HCN} \mathrm{mg} / \mathrm{kg})$ at twelve months. Serere tuber at eight and twelve months had the same reduction of cyanide content as that of Migyera tuber at six months $(6.67 \mathrm{HCN} \mathrm{mg/kg})$.

MH95/0183 had the highest level of reduction (20 HCN mg/kg) at 12 months while Serere had the least reduction $(6.67 \mathrm{HCN} \mathrm{mg} / \mathrm{kg})$. At six months MH95/0183 also had the highest level of reduction (8.33 HCN $\mathrm{mg} / \mathrm{kg}$ ) while Serere had the least (1.67 HCN $\mathrm{mg} / \mathrm{kg}$ ) content of cyanide 48 hours after uprooting. Serere exhibited the least deviation in cyanide content across all ages.

Data for cyanide content in the field and after forty eight hours was subjected to ANOVA in excel. A $p$ value of 0.10 obtained (alpha $=0.05$ ) for data collected in the field. The concentration of cyanide varied insignificantly $(p>0.05)$ therefore the null hypothesis
(Cassava is not ingested when cyanide level is at its highest that is before maturity) was accepted. On the other hand, the amount of cyanide content in the cassava varieties varied significantly post-harvest $(p<0.05)$.A $p$ value of 0.04 was obtained. Therefore, the null hypothesis (Post-harvest storage has no effect on cyanide level in cassava) was rejected.

\section{DiscuSSION}

Cyanide was extracted from all the tubers (27/27) tubers of the three cassava varieties (Migyera, Serere and MH95/0183) at all ages (six, eight and twelve months) used in this study. Cyanide content of the fresh samples used in this study ranged between 15 $\mathrm{HCN} \mathrm{mg/kg} \mathrm{to} 60 \mathrm{HCN} \mathrm{mg/kg}$ in all the farms. This is in contrast with Aalsbersberg et al. [10] on their study on determination of cyanide in twenty one Fijian cultivars. The cyanide content of these samples ranged between 14 and $121 \mathrm{HCN} \mathrm{mg/kg}$. This finding is similar to the report by Ubwa et al., [11], that documented different levels of cyanide content in three sweet cassava cultivars (Alhaji, Ochengbila and Onono) in three local government areas of Benue State ,Nigeria 
Farm A contained more cyanide content than Farm B and $\mathrm{C}$. The average cyanide content of the three varieties varied greatly at all ages with Migyera having the highest average level at twelve months As seen in the current study cyanide content in all the varieties at six months was above the WHO accepted value, which the body can tolerate $(10 \mathrm{HCN} \mathrm{mg} / \mathrm{kg})$. Therefore harvesting tubers of Migyera, Serere and MH95/0183 at any age less than twelve months for fresh use should be discouraged.

Migyera had the highest average level of cyanide content $(43.33 \mathrm{HCN} \mathrm{mg} / \mathrm{kg})$ at eight months in all the three farms. Serere had the least average cyanide content $(26.67 \mathrm{HCN} \mathrm{mg} / \mathrm{kg})$. Some reduction is observed in the level of cyanide from the six month tuber to the eight month tuber. This could probably imply that the higher the tuber stays in the soil before harvesting the lower the cyanide content [12].

This study reports variation of cyanide concentration with cultivar type. From the results it can be noted that the same variety of cassava had different cyanide content in different farms. These results are supported in the literature. Nassar et al. [13] state that genetics is a major factor that can influence the concentration of cyanogenic compounds in cassava. Environmental conditions, the physiological state of the plant, the method of cultivation employed, and the length of time of planting would be secondary factors. These results are in tandem with the findings of Gomez et al., [9] on the influence of cultivar and plant age on the chemical composition of field-grown cassava leaves and roots. They used two cassava varieties their study; M Col 1684, CN 342-170 and M Col 113.The cultivar M Col 1684 showed a higher cyanide concentration in the parenchyma (900 to $1000 \mathrm{mg} / \mathrm{kg} \mathrm{DM}$ ) than the other cultivars, which ranged from 100 to $200 \mathrm{mg} / \mathrm{kg}$ DM. The local cultivar (M Col 113) had the lowest cyanide content.A study carried out by Famurewa et al., 2014 on Cyanide reduction pattern of cassava (Mannihot Esculenta) as affected by variety and air velocity using fluidized bed dryer. The total cyanide contents for fresh cassava tested were $7.96 \mathrm{mg} / \mathrm{kg}$ and $8.43 \mathrm{mg} / \mathrm{kg}$ for TMS30572 and TMS98/0581 respectively. Total HCN ranged between 0.59 to $7.43 \mathrm{mg} / \mathrm{kg}$ for both varieties.

Migyera also had the highest average cyanide content $(28.33 \mathrm{HCN} \mathrm{mg/kg})$ while Serere had the least cyanide content $(16.67 \mathrm{HCN} \mathrm{mg} / \mathrm{kg}$ ) at twelve months. In the current study cyanide content values are seen to have greatly reduced between six and twelve months of harvest. These findings are similar to a study carried out by Obigbesan et al., [14] who carried out a study on evaluation of the yield and quality of some Nigerian cassava varieties as affected by age and nitrogen fertilizer application. Tubers of the cultivars 53101 and 60506 contained higher amounts of cyanide at 15 months than at 24 months in the experiments hence showing that cyanide concentration decreased with the age of the plant. The cyanide content of the cultivar 53101 was highest (310 ppm) at 15 months, and then decreased with increasing age of the plant, falling to $250 \mathrm{ppm}$ at 24 months. A study carried out by Chikezie et al., [17] on Cyanide and Aflatoxin Loads of Processed Cassava (Manihot esculenta) Tubers (Garri) in Njaba, Imo State, Nigeria showed that cyanide content of peeled cassava tubers was within the range of 40.7-52.0 mg hydrocyanic acid (HCN) equivalent/1000 g wet weight.

All the cassava tubers from MH95/0183, Serere and Migyera stored for forty eight hours after harvesting showed a decrease in cyanide content at all ages. These findings are similar to that of Ubwa et al., [11] in their study to determine effect of storage on cyanide content in three sweet cultivars in Benue State. In their study there was a slight change in the cyanide content. Alhaji cyanide content reduced from 42.91 $\mathrm{HCN} \mathrm{mg} / \mathrm{kg}$ to $40.80 \mathrm{HCN} \mathrm{mg/kg}$ after forty eight hours, Ochengbila cyanide content reduced from 51.15 $\mathrm{HCN} \mathrm{mg} / \mathrm{kg}$ to $45.95 \mathrm{HCN} \mathrm{mg} / \mathrm{kg}$, Onono cyanide content reduced from $55.32 \mathrm{HCN} \mathrm{mg} / \mathrm{kg}$ to $54 \mathrm{HCN}$ $\mathrm{mg} / \mathrm{kg}$.

Migyera had an overall average decrease of $29.4 \%$ after forty eight hours of storage after uprooting. These findings are lower compared to a similar study [10] carried out on Fiji variety in Australia which recorded an average decrease of only $39 \%$ after six days of storage. Serere had an almost similar record of $40 \%$ decrease at twelve months .MH95/0183 recorded 35\% decrease after storage. Basing on the deviations MH95/0183 had the highest deviation therefore postharvest storage was more effective in MH95/0183 while Serere was least affected by storage. The cassava tubers were noted to turn brown and rot after two days of storage and also exhibited post-harvest deterioration. Cassava is known generally have an acceptable shelf life of twenty four to forty eight hours after harvest. Two main types of post-harvest deteroriation are observed; primary physiological deteroriation which involves discolouration and secondary deteroriation which involves microbial spoilage [15]. A study carried out by Taye et al., [16] on Effect of storage and cooking practices on two cassava cultivars; Amarokello white and Umbure showed that lowest cyanide reduction was obtained when fresh tubers were placed on the ground for the three days for both cultivars however Amarokello exhibited the lowest reduction just like Serere in the current study.At six days of exposure to the ground the was remarkable decrease in cyanide content in both Amarokello white and Umbure.

\section{Conclusions}

The content of cyanide in Migyera, Serere and MH95/0183 ranged from $15 \mathrm{HCN} \mathrm{mg} / \mathrm{kg}$ to $30 \mathrm{HCN}$ $\mathrm{mg} / \mathrm{kg}$ at twelve months. The cyanide levels in Migyera, Serere and MH95/0183 at twelve months were above the limits of cyanide fit for human consumption by 
WHO (10 HCN mg/kg). Cyanide content for Migyera, Serere and MH95/0183 ranged between $10 \mathrm{HCN} \mathrm{mg/kg}$ to $30 \mathrm{HCN} \mathrm{mg/kg}$ at twelve months forty-eight hours after uprooting. Serere had the least cyanide content at all ages followed by MH95/0183 while Migyera had the highest cyanide content in field. Post-harvest storage was more effective in MH95/0183 than Migyera and Serere since it had the highest deviation in cyanide content.

\section{REFERENCES}

1. O'Hair S. Cassava: Tropical Research and Education Centre, University of Florida.1995.

2. Allem AC. the origin of Manihot esculenta crantz (Euphorbiaceae). Genetic resources and crop Evolution. 1994 Jan 1;41(3):133-50.

3. Olsen KM, Schaal BA. Microsatellite variation in cassava (Manihot esculenta, Euphorbiaceae) and its wild relatives: further evidence for a southern Amazonian origin of domestication. American journal of botany. $2001 \mathrm{Jan} ; 88(1): 131-42$.

4. Cock J. Cassava. New Potential for a neglected crop. Westview Press/Boulder, London. 1958;191

5. Valicourt J. Searching for cyanide.www.nordicfoodlab.org/2013/8/hydrogen cyanide as accessed on $14^{\text {th }}$ November 2016 0700hrs East African Time.2013.

6. Egan J. Rethinking construction. Department of Environment, Transport and the Region; 1998.

7. Haque MR, Bradbury JH. Preparation of linamarase solution from cassava latex for use in the cassava cyanide kit. Food chemistry. 1999 Nov $1 ; 67(3): 305-9$.

8. SAS. Institute User's guide Statistics, Version9.0 Inst. Inc. NC. USA. 2004.
9. Gosselin RE, Hodge HC, Smith RP, Gleason MN. Clinical toxicology of commercial products, 5th edn. Williams and Wilkins, Baltimore. pp III-61$63 ; 1984$.

10. Aalbersberg WG, Limalevu L. Cyanide content in fresh and processed Fijian cassava (Manihot esculenta) cultivars. Trop. Sci. 1991; 31: 249-56.

11. Ubwa ST, Otache AM, Igbum OG, Shambe T. Determination of Cyanide Content in Three Cassava varieties in three local governments in Benue State, Nigeria. Food and Nutrition Sciences. 2015; (6): 1078-1085.

12. Muchena FH, Wamicha WN, Njoroge CR. Detailed survey of the Jomo Kenyatta College of Agriculture and Technology, Juja (Kiambu District). Soil survey report; 1978.

13. Nassar NM, Alves J, de Souza E. Nutritive value and stature of a cassava (Mandioca), Manihot esculenta Crantz Hybrid. Gene Conserve. 2003;2(8):111-7.

14. Obigbesan GO, Agboola AA. An evaluation of the yield and quality of some Nigerian cassava varieties as affected by age and nitrogen fertilizer application. InProc. 3rd Int. Symp. Trop. Root Crops, Int. Inst. Trop. Agr., Ibadan, Nigeria. 1973: 321-326.

15. Booth RH, Coursey DG. Storage of cassava roots and related post-harvest problems. In Cassava processing and storage: proceedings of an Interdisciplinary Workshop 1974. IDRC, Ottawa, ON, CA.

16. Taye M, Biratu E. SINET. Ethiop. J.sci.1999; 22(1): 55-66

17. Chikezie PC, Ojiako OA. Toxicol Int. 2013 Sep;20(3):261-7. 